\title{
Effect of Biofield Treatment on Physical, Thermal, and Spectral Properties of SFRE 199-1 Mammalian Cell Culture Medium
}

\author{
Mahendra Kumar Trivedi ${ }^{1}$, Alice Branton ${ }^{1}$, Dahryn Trivedi ${ }^{1}$, Gopal Nayak ${ }^{1}$, Khemraj Bairwa ${ }^{2}$, \\ Snehasis Jana ${ }^{2, *}$ \\ ${ }^{1}$ Trivedi Global Inc., Henderson, NV, USA \\ ${ }^{2}$ Trivedi Science Research Laboratory Pvt. Ltd., Bhopal, Madhya Pradesh, India
}

Email address:

publication@trivedisrl.com (S. Jana)

\section{To cite this article:}

Mahendra Kumar Trivedi, Alice Branton, Dahryn Trivedi, Gopal Nayak, Khemraj Bairwa, Snehasis Jana. Effect of Biofield Treatment on Physical, Thermal, and Spectral Properties of SFRE 199-1 Mammalian Cell Culture Medium. Advances in Biochemistry.

Vol. 3, No. 6, 2015, pp. 77-85. doi: 10.11648/j.ab.20150306.13

\begin{abstract}
SFRE 199-1 medium (SFRE-M) is important mammalian cell culture medium, used for the culture of primary cells of mammals such as baboon kidney cells. The present study was attempted to evaluate the impact of biofield energy treatment on the physical, thermal and spectral properties of SFRE-M. The study was accomplished in two groups; one was set as control while another was subjected to Mr. Trivedi's biofield energy treatment and coded as treated group. Subsequently, the control and treated samples were analyzed using various analytical techniques. The CHNO analysis showed about 2.16, 4.87, and $5.89 \%$ decrease in percent contents of carbon, hydrogen, and oxygen, respectively; while $9.49 \%$ increase in nitrogen contents of treated sample as compared to the control. X-ray diffraction (XRD) analysis showed $7.23 \%$ decrease in crystallite size of treated sample as compared to the control. The thermogravimetric analysis (TGA) analysis showed the increase in onset temperature of thermal degradation by $19.61 \%$ in treated sample with respect to the control. The control sample showed the $48.63 \%$ weight loss during the thermal degradation temperature $\left(\mathrm{T}_{\max }\right)$ while the treated sample showed only $13.62 \%$ weight loss during the $\mathrm{T}_{\max }$. The differential scanning calorimetry (DSC) analysis showed the $62.58 \%$ increase in the latent heat of fusion of treated sample with respect to the control sample. The Fourier transform infrared spectroscopy (FT-IR) spectrum of treated SFRE-M showed the alteration in the wavenumber of C-O, C-N and C-H vibrations in the treated sample as compared to the control. Altogether, the XRD, TGA-DTG, DSC, and FT-IR analysis suggest that Mr. Trivedi's biofield energy treatment has the impact on physical, thermal and spectral properties of SFRE-M. The treated SFRE-M was more thermal stable than the control SFRE-M and can be used as the better culture media for mammalian cell culture.
\end{abstract}

Keywords: Biofield Energy Treatment, SFRE-Medium, Elemental Analysis, X-ray Diffraction, Fourier Transform Infrared Spectroscopy

\section{Introduction}

Medium M-199 is a well-defined nutritional source for cell culture media, developed in 1950 by Morgan et al. [1, 2]. It is the combinations of amino acids, vitamins and other factors, which exhibited the best growth of explanted tissue in the in vitro studies [3]. It was initially designed for nutritional studies to promote the growth of primary chick embryo heart and fibroblast cells in the absence of serum supplement [3, 4]. Although, the M-199 medium is also useful with serum for growth of a wide range of cell types such as non- transformed chicken, monkey, and human cells. The SFRE 199-1 medium (SFRE-M) is the modified form of medium 199, and developed for the growth and maintenance of mammalian cell culture (such as primary baboon kidney cells) [5]. It is obtained by supplementing the medium M-199 with sodium pyruvate, zinc sulfate, and increasing arginine$\mathrm{HCl}$, cystine, cysteine, L-glutamic acid, L-glutamine, glycine, tyrosine, histidine, and glucose to maximally active nontoxic concentrations [6].

Sterilization process plays a significant role on the quality of culture media. The autoclaving (heat treatment) is the principle method of culture media sterilization [7]. This heat 
treatment of complex culture media may result to nutrient destruction via the direct thermal degradation or by the chemical reactions between the components [8]. Therefore, an alternate method is required, which can enhance the overall stability of the culture media such as SFRE-M [9].

Recently, the energy healing therapies have been reported for several beneficial effects throughout the word. Biofield energy treatment is one of the energy therapies that has been reported to alter the various physicochemical properties of organic compounds [10] and organic products [11].

The energy medicines have been categorized by National Center for Complementary and Alternative Medicine (NCCAM) under the CAM therapies [12]. There are several proposed mechanism and explanations are offered to support the biofield energy therapies. Consciousness is one of the possible mechanisms, which includes healer's intent to heal, may interact with the physical realm [13]. Likewise, physical resonance is another theory that includes subtle energies. According to this theory, the energy might be exchange between the energy fields of healer and patient [14]. The healer or practitioner of energy medicine harness the energy from universe and transmit it to the object (living or nonliving), which is called biofield energy treatment. Mr. Trivedi is a renowned practitioner of energy medicine and his unique biofield energy treatment is known as The Trivedi Effect ${ }^{\mathbb{R}}$ that has been studied in the field of agricultural science research [15], biotechnology research [16], and microbiology research [17], etc.

After conceiving the significant impact of biofield energy treatment in different field of science, the present study was attempted to evaluate its impact on the culture media such as SFRE-M culture media. The biofield energy treated SFRE-M was analyzed along with the control sample using several analytical techniques like elemental (CHNO) analysis, X-ray diffractometry (XRD), thermogravimetric analysis-derivative thermogravimetry (TGA-DTG), DSC, and Fourier transform infrared (FT-IR) spectroscopy. The data of treated sample was compared with that of control as well as reported literature data.

\section{Materials and Methods}

\subsection{Study Design}

The SFRE 199-1 media (SFRE-M) was procured from HiMedia Laboratories, India. It consists with several inorganic salts, vitamins, amino acids, sugars, etc. (Table 1). The SFRE-M was divided into two groups; one was kept as control (without treated) while another was handed over to Mr. Trivedi to render the biofield energy treatment under laboratory conditions. Mr. Trivedi provided the biofield energy treatment to the treated group via his unique energy harnessing process through the thought transmission (without touching the sample). Then, both the control and treated samples were explored with respect to physicochemical and spectroscopic properties using various techniques like elemental (CHNO) analysis, XRD, TGA-DTG, FT-IR and
UV-vis spectroscopy.

Table 1. Chemical composition of SFRE 199-1 medium.

\begin{tabular}{|c|c|c|c|}
\hline Ingredients & $\mathrm{mg} / \mathrm{L}$ & Ingredients & $\mathrm{mg} / \mathrm{L}$ \\
\hline INORGANIC SALTS & & VITAMINS & \\
\hline Sodium chloride & 8000.000 & Choline chloride & 0.500 \\
\hline Potassium chloride & 400.000 & Retinol Acetate & 0.140 \\
\hline $\begin{array}{l}\text { Calcium chloride } \\
\text { dihydrate }\end{array}$ & 185.000 & Calciferol & 0.100 \\
\hline $\begin{array}{l}\text { Magnesium sulphate } \\
\text { anhydrous }\end{array}$ & 97.720 & L-Ascorbic acid & 0.050 \\
\hline $\begin{array}{l}\text { Potassium phosphate } \\
\text { monobasic }\end{array}$ & 60.000 & i-Inositol & 0.050 \\
\hline Sodium acetate & 50.000 & $\begin{array}{l}\text { p-Amino benzoic } \\
\text { acid (PABA) }\end{array}$ & 0.050 \\
\hline $\begin{array}{l}\text { Sodium phosphate dibasic } \\
\text { anhydrous }\end{array}$ & 47.860 & $\begin{array}{l}\text { Niacin }+ \\
\text { Niacinamide }(1: 1)\end{array}$ & 0.050 \\
\hline Ferric nitrate nonahydrate & 0.720 & $\begin{array}{l}\text { Pyridoxal } \\
\text { hydrochloride }\end{array}$ & 0.025 \\
\hline $\begin{array}{l}\text { Zinc sulphate } \\
\text { heptahydrate }\end{array}$ & 0.100 & $\begin{array}{l}\text { Pyridoxine } \\
\text { hydrochloride }\end{array}$ & 0.025 \\
\hline AMINO ACIDS & & $\begin{array}{l}\text { Menadione sodium } \\
\text { bisulphite }\end{array}$ & 0.016 \\
\hline L-Glutamine & 300.000 & $\begin{array}{l}\text { Folic acid }+ \\
\text { Riboflavin }(1: 1)\end{array}$ & 0.020 \\
\hline L-Arginine hydrochloride & 150.000 & D-Ca-Pantothenate & 0.010 \\
\hline L-Tyrosine disodium salt & 116.000 & D-Biotin & 0.010 \\
\hline Glycine & 100.000 & $\begin{array}{l}\text { DL-Tocopherol } \\
\text { phosphate disodium } \\
\text { salt }\end{array}$ & 0.010 \\
\hline L-Glutamic acid & 75.000 & $\begin{array}{l}\text { Thiamine } \\
\text { hydrochloride }\end{array}$ & 0.010 \\
\hline L-Lysine hydrochloride & 70.000 & OTHERS & \\
\hline L-Leucine & 60.000 & D-Glucose & 2000.000 \\
\hline $\begin{array}{l}\text { L-Cystine } \\
\text { dihydrochloride }\end{array}$ & 43.800 & $\begin{array}{l}\text { D-(+)-Galactose } \\
\text { anhydrous }\end{array}$ & 1000.000 \\
\hline L-Proline & 40.000 & Sodium pyruvate & 150.000 \\
\hline $\begin{array}{l}\text { L-Histidine hydrochloride } \\
\text { monohydrate }\end{array}$ & 40.000 & Adenine sulphate & 10.000 \\
\hline L-Aspartic acid & 30.000 & Phenol red & 10.000 \\
\hline L-Threonine & 30.000 & Polysorbate 80 & 4.900 \\
\hline L-Alanine & 25.000 & $\begin{array}{l}\text { Adenosine } \\
\text { triphosphate } \\
\text { disodium }\end{array}$ & 1.000 \\
\hline L-Phenylalanine & 25.000 & $\begin{array}{l}\text { Deoxyribose }+ \\
\text { Ribose }(1: 1)\end{array}$ & 1.000 \\
\hline L-Serine & 25.000 & Hypoxanthine & 0.354 \\
\hline L-Valine & 25.000 & Xanthine & 0.344 \\
\hline L-Isoleucine & 20.000 & $\begin{array}{l}\text { Guanine } \\
\text { hydrochloride }\end{array}$ & 0.300 \\
\hline L-Methionine & 15.000 & $\begin{array}{l}\text { Thymine +Uracil } \\
(1: 1)\end{array}$ & 0.600 \\
\hline Hydroxy-L-Proline 1 & 10.000 & $\begin{array}{l}\text { Adenosine } \\
\text { monophosphate }\end{array}$ & 0.200 \\
\hline L-Tryptophan & 10.000 & Cholesterol & 0.200 \\
\hline L-Cysteine (free base) & 4.000 & Glutathione reduced & 0.050 \\
\hline
\end{tabular}

\subsection{Elemental (CHNO) Analysis}

The control and treated samples of SFRE-M were analyzed for their elemental composition, carbon (C), hydrogen $(\mathrm{H})$, nitrogen $(\mathrm{N})$, oxygen $(\mathrm{O})$, and sulfur $(\mathrm{S})$. The analysis was done using Model Flash EA 1112 Series, Thermo Finnigan Italy. This analyzer combusts and then 
converts the $\mathrm{C}, \mathrm{H}, \mathrm{N}$ and $\mathrm{O}$ sample elements to simple gases, i.e. $\mathrm{CO}_{2}, \mathrm{H}_{2} \mathrm{O}, \mathrm{N}_{2}$, and $\mathrm{O}_{2}$, which were determined quantitatively to deduced the net contents of respective element in the sample. The percentage change in element of the treated sample with respect to the control was determined using the following equation.

$$
\% \text { Change in element }(\mathrm{C}, \mathrm{H}, \mathrm{N} \text {, or } \mathrm{O})=\left[\left(\mathrm{E}_{\mathrm{T}}-\mathrm{E}_{\mathrm{C}}\right) / \mathrm{E}_{\mathrm{C}}\right] \times 100
$$

Here, $\mathrm{E}_{\mathrm{T}}$ and $\mathrm{E}_{\mathrm{C}}$ are the element in control and treated samples, respectively.

\subsection{XRD Study}

The XRD analysis of control and treated samples of SFRE-M was done on Phillips (Holland PW 1710) X-ray diffractometer with copper anode and nickel filter. The wavelength of XRD instrument was set to $1.54056 \AA$. The percent change in crystallite size $(\mathrm{G})$ was calculated using following equation:

$$
\mathrm{G}=\left[\left(\mathrm{G}_{\mathrm{T}}-\mathrm{G}_{\mathrm{C}}\right) / \mathrm{G}_{\mathrm{C}}\right] \times 100
$$

Here, $G_{T}$ and $G_{C}$ are average crystallite size of treated and control samples, respectively.

\subsection{TGA-DTG Analysis}

The TGA-DTG analysis of control and treated sample was carried out on Mettler Toledo simultaneous TGA-DTG analyzer. The analytes were heated up to $400^{\circ} \mathrm{C}$ from room temperature at the heating rate of $5^{\circ} \mathrm{C} / \mathrm{min}$ under air atmosphere. The onset temperature of thermal degradation and temperature at which maximum weight loss occur $\left(\mathrm{T}_{\max }\right)$ in samples were obtained from TGA-DTG thermogram.
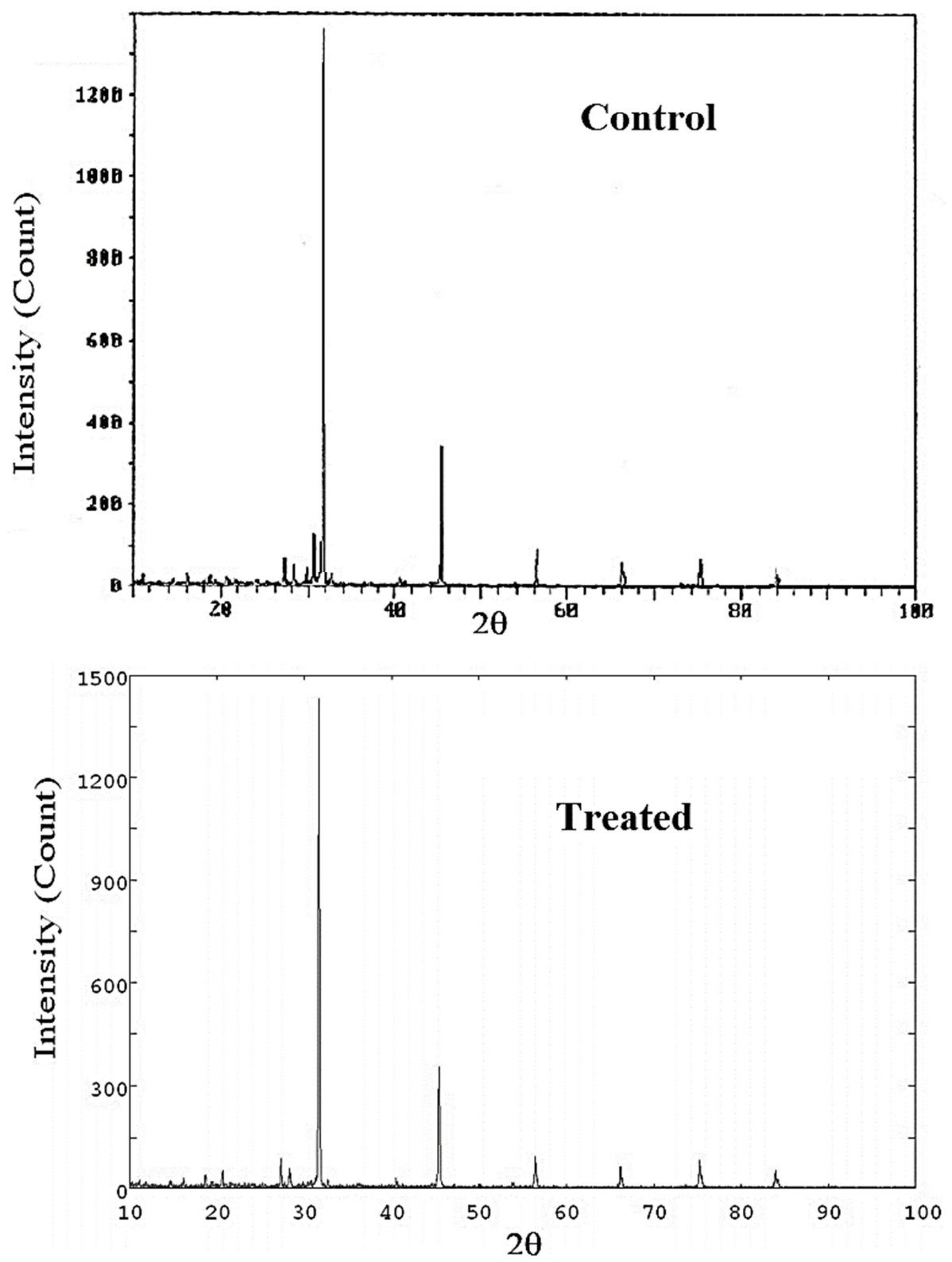

Fig. 1. XRD diffractograms of control and treated SFRE 199-1 medium. 


\subsection{DSC Study}

The melting temperature and latent heat of fusion of control and treated SFRE-M were determined using the Pyris-6 Perkin Elmer differential scanning calorimeter. The samples were heated upto $300^{\circ} \mathrm{C}$ at the heating rate of $10^{\circ} \mathrm{C} /$ min under air atmosphere with air flow rate of 5 $\mathrm{mL} / \mathrm{min}$.

\subsection{FT-IR Spectroscopic Characterization}

The FT-IR spectroscopy was carried out to evaluate the effect of biofield energy treatment on force constant and bond strength in chemical structure [18]. The samples for FTIR analysis were prepared with spectroscopic grade $\mathrm{KBr}$ into pellets. The spectra were recorded on Shimadzu's Fourier transform infrared spectrometer (Japan) with the frequency array of $500-4000 \mathrm{~cm}^{-1}$.

\section{Results and Discussion}

\subsection{Elemental (CHNO) Analysis}

The elemental analysis is used to quantify the percent content of elements present in the organic compounds or products. The impact of biofield energy treatment on $\mathrm{C}, \mathrm{H}$, $\mathrm{N}$, and $\mathrm{O}$ is reported in Table 2. The result showed that content of carbon, hydrogen and oxygen were decreased with $2.16,4.87$, and $5.89 \%$, respectively in the biofield treated SFRE-M as compared to the control. On the other hand, the content of nitrogen element was increased significantly by $9.49 \%$ in treated sample with respect to the control SFRE-M.

Table 2. CHNO analysis data of control and treated SFRE 199-1 medium.

\begin{tabular}{llll}
\hline Element & Control & Treated & \% Change \\
\hline Carbon & 13.173 & 12.889 & -2.16 \\
Hydrogen & 2.135 & 2.031 & -4.87 \\
Nitrogen & 1.054 & 1.154 & 9.49 \\
Oxygen & 12.40 & 11.67 & -5.89 \\
\hline
\end{tabular}

Although, the mammalian cell culture require numerous essential components, but the nitrogen content is the principal requirement for the proper growth and development of primary mammalian cells $[19,20]$. There are several nitrate salts and amino acids used as the source of nitrogen in the culture medium [21]. In the present study, the nitrogen content was increased significantly in the treated sample as compared to the control. This might be useful for the better growth of mammalian cells as compared to the control SFRE-M.

\subsection{XRD Analysis}

The XRD diffractograms of SFRE-M (control and treated) samples are shown in Fig. 1. The XRD diffractograms of both the samples (i.e. control and treated SFRE-M) showed the sharp and intense peaks, which suggest the crystalline nature of both samples. The XRD diffractogram of control

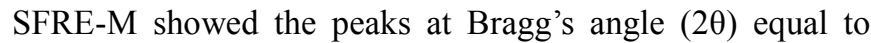
$27.24^{\circ}, 28.24^{\circ}, 29.63^{\circ}, 30.55^{\circ}, 31.52^{\circ}$, and $45.26^{\circ}$. Similarly, the XRD diffractogram of treated SFRE-M exhibited the XRD peaks at $2 \theta$ equal to $27.33^{\circ}, 28.34^{\circ}, 31.67^{\circ}, 32.66^{\circ}$, $40.48^{\circ}$, and $45.41^{\circ}$.

The XRD analysis showed the crystallite size of the control and treated samples as 51.72 and $61.45 \mathrm{~nm}$, respectively. The result showed $18.82 \%$ increase in the crystallite size of treated sample as compared to the control (Fig. 2).

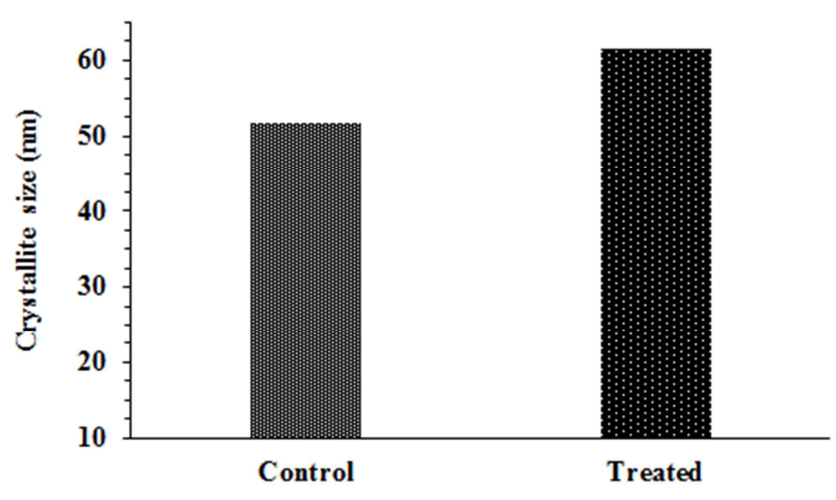

Fig. 2. Crystallite size of control and treated SFRE 199-1 medium.

It is assumed that biofield energy might induce some internal strain in the treated molecules and resulted in the reorientation of neighboring planes, which is also called as atomic displacement $[22,23]$. This might lead to increase the crystallite size in the treated sample.

\subsection{TGA-DTG Analysis}

The TGA-DTG thermogram of SFRE-M samples (control and treated) are shown in Fig. 3 and data are presented in Table 3.

The TGA thermogram of control sample exhibited the initiation (onset) of thermal degradation at about $102^{\circ} \mathrm{C}$, which was ended (endset) at about $221{ }^{\circ} \mathrm{C}$. Likewise, the TGA thermogram of the treated SFRE-M exhibited the initial (onset) thermal degradation temperature at about $122^{\circ} \mathrm{C}$ that was terminated (endset) at about $200^{\circ} \mathrm{C}$.

Table 3. Thermal analysis of control and treated samples of SFRE 199-1 medium.

\begin{tabular}{lll}
\hline Parameter & Control & Treated \\
\hline Onset temperature $\left({ }^{\circ} \mathrm{C}\right)$ & 102.00 & 122.00 \\
Endset temperature $\left({ }^{\circ} \mathrm{C}\right)$ & 221.00 & 200.00 \\
$\mathrm{~T}_{\max }\left({ }^{\circ} \mathrm{C}\right)$ & 162.00 & 156.00 \\
Latent heat of fusion $(\mathrm{J} / \mathrm{g})$ & 44.79 & 72.82 \\
Melting point $\left({ }^{\circ} \mathrm{C}\right)$ & 145.76 & 149.83 \\
\hline
\end{tabular}

$\mathrm{T}_{\max }$ : temperature at maximum weight loss occurs

The result indicated about $19.61 \%$ increase in the onset temperature of thermal degradation in biofield energy treated sample with respect to the control. Moreover, the maximum thermal degradation temperature $\left(\mathrm{T}_{\max }\right)$ of control sample 
was observed at about $162^{\circ} \mathrm{C}$ with about $48.63 \%$ weight loss; while the treated sample showed the $\mathrm{T}_{\max }$ at $156^{\circ} \mathrm{C}$ with only $13.62 \%$ weight loss. This indicated that the percentage of weight loss during the thermal degradation was less in the treated sample with respect to the control. It suggests the possible increase in the thermal stability of treated sample as compared to the control $[24,25]$. Further, the result showed about $3.70 \%$ decrease in $\mathrm{T}_{\max }$ of treated SFRE-M as compared to the control. This might be occurred due to the alteration in internal energy via biofield energy treatment, which may lead to early phase of evaporation in treated sample as compared to the control [26].
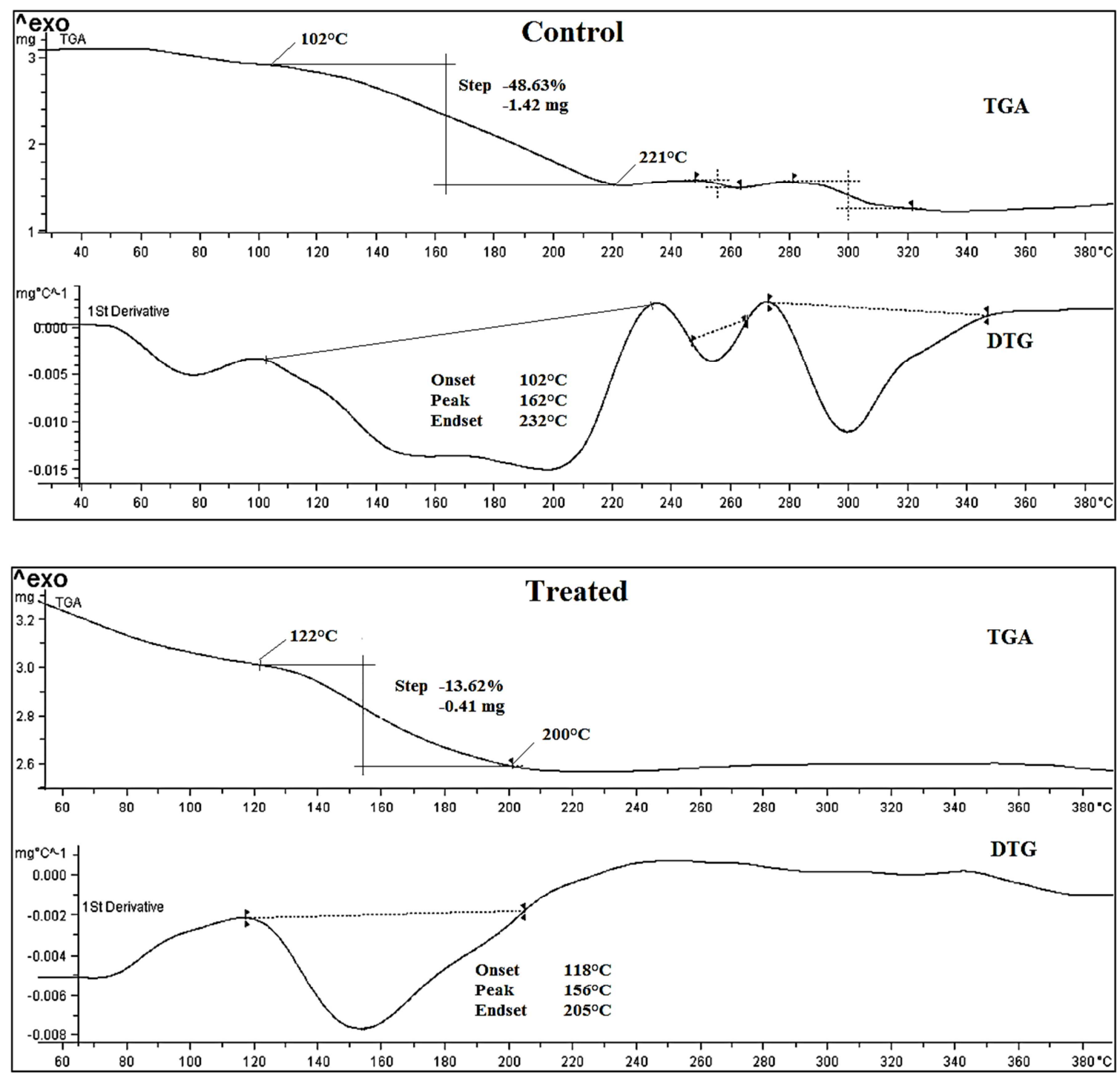

Fig. 3. TGA-DTG thermograms of control and treated SFRE 199-1 medium.

\subsection{DSC Analysis}

DSC analysis was performed to determine the melting temperature and latent heat of fusion $(\Delta \mathrm{H})$ of control and treated TPP samples. A substantial amount of interaction force is present in the atomic bonds of any substance that hold the atoms at their positions. The energy required to overcome the interaction force of phase change i.e. solid into liquid, is called as the $\Delta \mathrm{H}$. DSC thermogram (Fig. 4) of SFRE-M showed the melting temperature at $145^{\circ} \mathrm{C}$ in control and $149.83^{\circ} \mathrm{C}$ in treated sample (Table 2).

The result showed about $2.79 \%$ increase in the melting temperature of the treated sample of SFRE-M as compared to the control. Moreover, the DSC thermogram exhibited the latent heat of fusion i.e. $44.79 \mathrm{~J} / \mathrm{g}$ in control and $72.82 \mathrm{~J} / \mathrm{g}$ in the treated sample of SFRE-M. The result showed about $62.58 \%$ increase in the latent heat of fusion of treated sample with respect to the control sample. This might be due to increase in intermolecular force in the treated SFRE-M with respect to the control. As a result, the treated SFRE-M sample probably required more energy $(\Delta \mathrm{H})$ to change the phase from solid to liquid as compared to the control. Formerly, our group has reported that biofield energy treatment caused the changes in $\Delta \mathrm{H}$ in lead and tin powders [27]. Therefore, it is supposed that biofield treatment might alter the intermolecular interaction forces of treated SFRE-M molecules, which may lead to alteration in latent heat of fusion. 

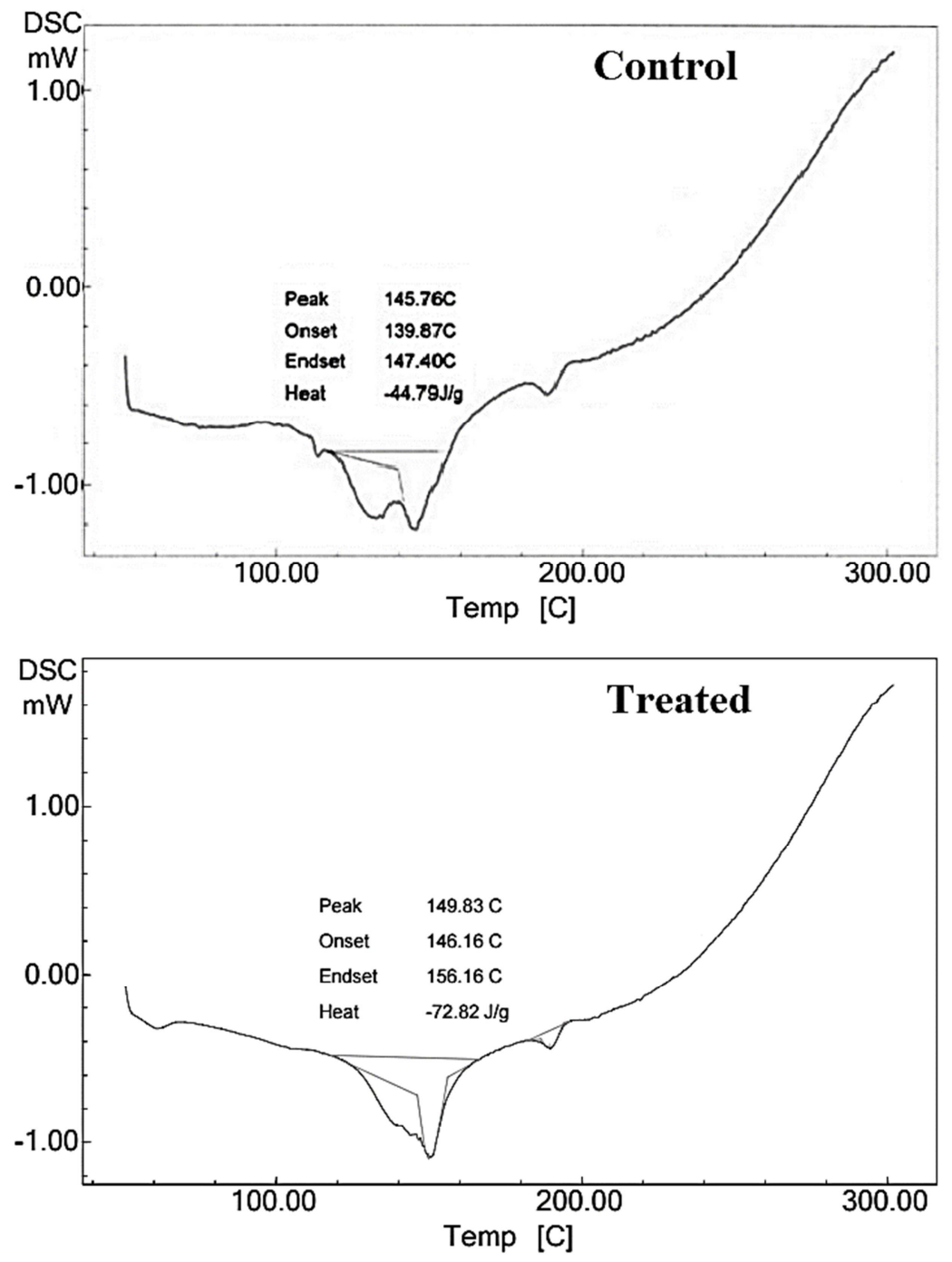

Fig. 4. DSC thermograms of control and treated SFRE 199-1 medium.

\subsection{FT-IR Spectroscopic Analysis}

FT-IR spectra of the control and treated SFRE 199-1 M are shown in Fig. 5. The SFRE-M molecule contains O-H, N-H, $\mathrm{C}-\mathrm{H}, \mathrm{C}=\mathrm{C}, \mathrm{C}=\mathrm{O}, \mathrm{C}-\mathrm{C}, \mathrm{C}-\mathrm{Cl}$ groups of vibrations. A broad peak in the frequency array of 2900 to $3600 \mathrm{~cm}^{-1}$ in both the control and treated samples may be due to O-H or N-H stretching. The vibrational peak appeared in the region of $2817-2893 \mathrm{~cm}^{-1}$ in the control sample that might be due to the $\mathrm{C}-\mathrm{H}$ stretching. This frequency region was shifted in the treated sample and observed at 2833-2902 $\mathrm{cm}^{-1}$, which indicated a possible increase in the bond strength of $\mathrm{C}-\mathrm{H}$ group in the treated sample with respect to the control. The IR peaks observed at $1629 \mathrm{~cm}^{-1}$ (control) and $1627 \mathrm{~cm}^{-1}$ (treated) were might be attributed to the amide or acidic $\mathrm{C}=\mathrm{O}$ group of amino acids present in the SFRE-M. Vibrational peak at $1411 \mathrm{~cm}^{-1}$ in control and treated sample might assign to $\mathrm{C}-\mathrm{H}$ bending.

The peak observed at $1355 \mathrm{~cm}^{-1}$ in control sample and $1359 \mathrm{~cm}^{-1}$ in treated sample were possibly due to the $\mathrm{N}=\mathrm{O}$ symmetric stretching in amino acid. Likewise, the IR peak at
$1326 \mathrm{~cm}^{-1}$ in control and $1328 \mathrm{~cm}^{-1}$ in the treated sample was possibly due to the $\mathrm{S}=\mathrm{O}$ stretching of sulfate salts, present in the SFRE-M. Moreover, the peaks at $1247 \mathrm{~cm}^{-1}$ (control) and $1244 \mathrm{~cm}^{-1}$ (treated) were might be due to $\mathrm{C}-\mathrm{C}$ stretching. The vibrational peak appeared at 1024 and $1149 \mathrm{~cm}^{-1}$ in control sample were might be due to $\mathrm{C}-\mathrm{O}$ stretching. This was appeared at slightly downstream region i.e. at 1022 and 1141 $\mathrm{cm}^{-1}$ in the treated sample, which indicated a possible decrease in the bond strength of $\mathrm{C}-\mathrm{O}$ bond in the treated sample with respect to the control. The vibrational peak at $1047 \mathrm{~cm}^{-1}$ in control sample, which might be due to C-N stretching that was shifted to upstream region of IR frequency i.e. at $1060 \mathrm{~cm}^{-1}$ after the biofield treatment. It suggested that the force constant of $\mathrm{C}-\mathrm{N}$ bond in the treated sample was possibly increased as compared to the control. Likewise, the peaks at $848 \mathrm{~cm}^{-1}, 769 \mathrm{~cm}^{-1}$, and $623 \mathrm{~cm}^{-1}$ in control sample were might be attributed to aromatic breathing, S-N stretching and metal-halide stretching, respectively. These peaks were correspondingly appeared at $846 \mathrm{~cm}^{-1}, 767 \mathrm{~cm}^{-1}$, and $617 \mathrm{~cm}^{-1}$ in the treated sample. 


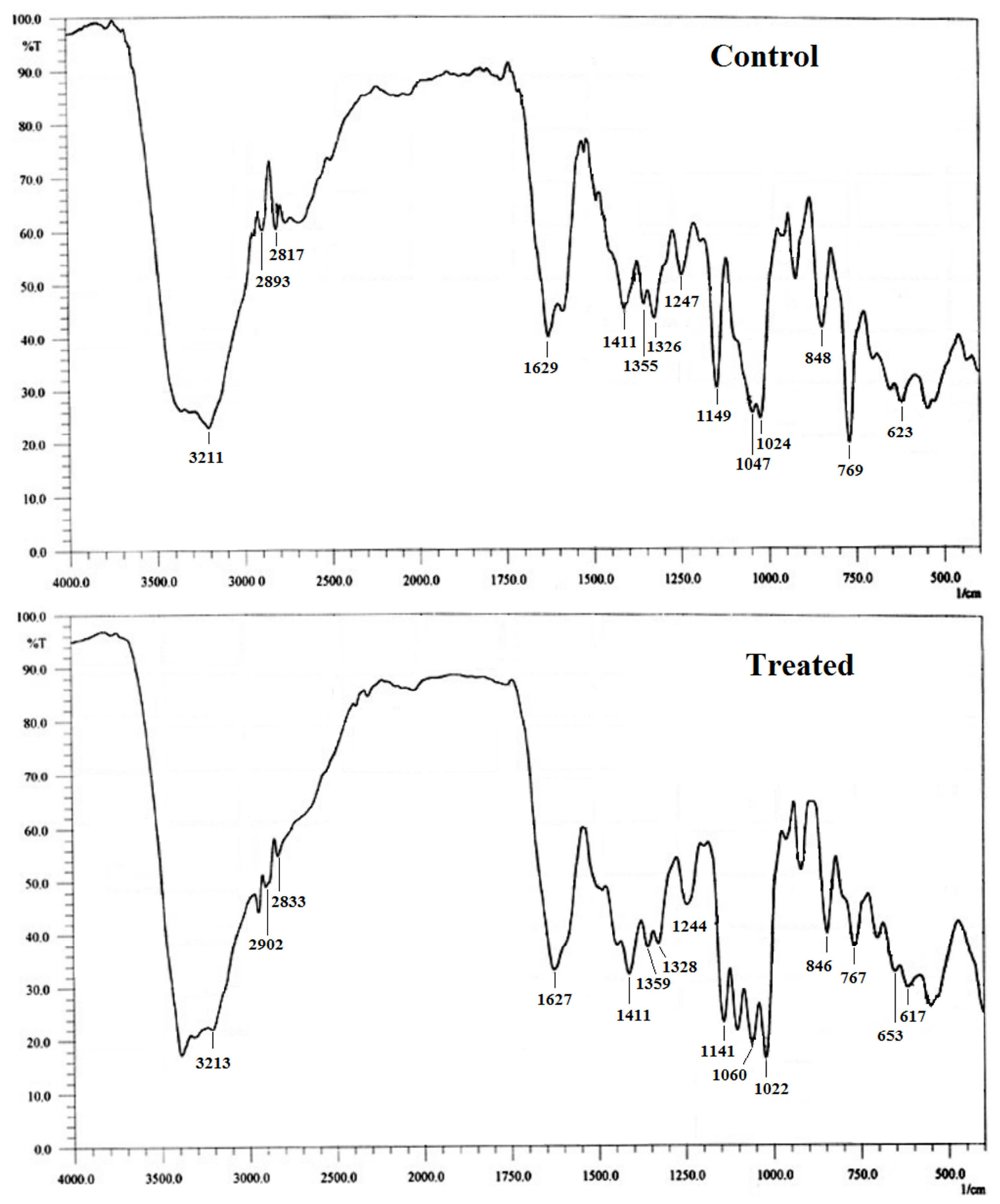

Fig. 5. FT-IR spectra of control and treated (T1 and T2) SFRE 199-1 medium.

Frequency $(v)$ of stretching vibrational peak is mainly depends on two factors i.e. force constant $(\mathrm{k})$ and reduced mass $(\mu)$, which can be explained by following equation $[18$, 28] $v=1 / 2 \pi \mathrm{c} \sqrt{ }(\mathrm{k} / \mu)$; here, $\mathrm{c}$ is the speed of light.

At the constant $\mu$, the frequency is directly proportional the force constant [29]. Based on this, it is presumed that force constant of some bond such as $\mathrm{C}-\mathrm{H}$ and $\mathrm{C}-\mathrm{N}$ might increase in the treated sample, which might lead to increase in the stability of treated molecules with respect to the control. The thermal stability data was also support the increased stability of treated SFRE-M with respect to the control.

\section{Conclusion}

In conclusion, the present study showed the substantial alteration in the percent of $\mathrm{C}, \mathrm{H}, \mathrm{N}$, and $\mathrm{O}$ element of treated sample by $2.16,4.87,9.49$, and $5.89 \%$, respectively as compared to the control sample. The XRD study suggested the crystalline nature of both the control and treated samples. Moreover, the crystallite size of treated sample was decreased by $18.82 \%$ with respect to the control sample. The TGA-DTG study showed about $19.61 \%$ increase in the initiation temperature of thermal degradation; while the 
percent weight loss during the maximum thermal decomposition temperature was also reduced significantly in the treated sample with respect to the control. This showed the increase in the thermal stability of treated SFRE-M as compared to the control. The DSC analysis showed the increased in the melting temperature $(2.79 \%)$ and latent heat of fusion $(62.58 \%)$ of treated sample with respect to the control. The FT-IR data showed the alteration in the vibrational frequency of some groups like $\mathrm{C}-\mathrm{H}, \mathrm{C}-\mathrm{O}$, and $\mathrm{C}$ $\mathrm{N}$ in treated sample with respect to the control. This might be due to the increase in force constant and bond strength of respective groups in treated SFRE-M molecule as compared to the control.

Overall, the data suggest that Mr. Trivedi's biofield energy treatment exhibited the significant impact on the physical, thermal and spectral properties of SFRE-M. Based on this, it is presumed that Mr. Trivedi's biofield energy treatment can modulate the physicochemical properties of SFRE-M so that it could be utilized as a better medium for the cell culture of primary mammalian cell in vitro.

\section{Abbreviations}

NCCAM: National Center for Complementary and Alternative Medicine;

NIH: National Institute of Health;

XRD: X-ray diffraction;

TGA: Thermogravimetric analysis;

DTG: Derivative Thermogravimetry

\section{Acknowledgements}

The authors would like to thank the Trivedi Master Wellness, Trivedi Science, and Trivedi Testimonials for their sturdy support during this study. Authors would also like to acknowledge the whole team of MGV pharmacy college, Nashik for the instrumental facility, used in this work.

\section{References}

[1] Taylor-Papadimitriou J, Shearer M, Watling D (1978) Growth requirements of calf lens epithelium in culture. J Cell Physiol 95: 95-103.

[2] Mitsuhashi, J. (2012) Invertebrate tissue culture methods. Springer science \& business media.

[3] http:/himedialabs.com/TD/AT044.pdf.

[4] http://www.bioind.com/page_14351.

[5] http://www.himedialabs.com/intl/en/products/100000080/Ani mal-Cell-Culture-Classical-Media-Mammalian-Cell-Culture.

[6] Weiss SA, Lester TL, Kalter SS, Heberling RL (1980) Chemically Defined serum-free media for the cultivation of primary cells and their susceptibility to viruses. In Vitro 16: 616-28.

[7] Rivera-Posada J, Caballes CF, Pratchett MS (2013) Lethal doses of oxbile, peptones and thiosulfate-citrate-bile-sucrose agar (TCBS) for Acanthaster planci; exploring alternative population control options. Mar Pollut Bull 75: 133-139.

[8] Basu S, Pal A, Desai PK (2005) Quality control of culture media in a microbiology laboratory. Ind J Med Microbiol 23: $159-163$.

[9] Ellaiah P, Srinivasulu B, Adinarayana K (2002) A review on microbial alkaline proteases. J Sci Ind Res 61: 690-704.

[10] Trivedi MK, Patil S, Shettigar H, Singh R, Jana S (2015) An impact of biofield treatment on spectroscopic characterization of pharmaceutical compounds. Mod Chem appl 3: 159.

[11] Trivedi MK, Nayak G, Patil S, Tallapragada RM, Jana S, Mishra RK (2015) Bio-field treatment: An effective strategy to improve the quality of beef extract and meat infusion powder. J Nutr Food Sci 5: 389.

[12] NIH, National center for complementary and alternative medicine. CAM Basics. Publication 347. [October 2, 2008]. Available at: http://nccam.nih.gov/health/whatiscam/.

[13] Jahn RG, Dunne BJ (1988) Margins of reality: The role of consciousness in the physical world. San Diego, CA: Harcourt Brace Jovanovich.

[14] Rosch PJ. (2009) Bioelectromagnetic and subtle energy medicine. The interface between mind and matter. Longevity, regeneration and optimal health, New York Academy of Science.

[15] Sances F, Flora E, Patil S, Spence A, Shinde V (2013) Impact of biofield treatment on ginseng and organic blueberry yield. Agrivita, J Agric Sci 35.

[16] Patil SA, Nayak GB, Barve SS, Tembe RP, Khan RR (2012) Impact of biofield treatment on growth and anatomical characteristics of Pogostemon cablin (Benth.). Biotechnology 11: $154-162$.

[17] Trivedi MK, Patil S, Shettigar H, Mondal SC, Jana S (2015) An impact of biofield treatment: antimycobacterial susceptibility potential using BACTEC 460/MGIT-TB system. Mycobact Dis 5: 189.

[18] Pavia DL, Lampman GM, Kriz GS (2001) Introduction to spectroscopy. (3rdedn), Thomson learning, Singapore.

[19] Sato JD, Kan M (2001) UNIT 1.2 Media for culture of mammalian cells. Current protocols in cell biology.

[20] Marquis CP. Mammalian Cell Culture. Biotechnology, 1. http://www.eolss.net/sample-chapters/c17/e6-58-01-04.pdf.

[21] Yang Z, Xiong HR (2012) Culture conditions and types of growth media for mammalian cells.

[22] Paiva-Santos CO, Gouveia H, Las WC, Varela JA (1999) Gauss-Lorentz size-strain broadening and cell parameters analysis of $\mathrm{Mn}$ doped $\mathrm{SnO}_{2}$ prepared by organic route. Mat Struct 6: 111-115.

[23] Zhang K, Alexandrov IV, Kilmametov AR, Valiev RZ, Lu K (1997) The crystallite-size dependence of structural parameters in pure ultrafine-grained copper. J Phys D 30: 3008-3015.

[24] Huang FY (2012) Thermal properties and thermal degradation of cellulose tri-stearate (CTs). Polymers 4: 1012-1024.

[25] Rudnik E (2010) Compostable polymer materials. Elsevier, Oxford, UK. 
[26] Sa J (2014) Fuel production with heterogeneous catalysis. CRC Press, Taylor and Francis group LLC., FL, USA.

[27] Trivedi MK, Patil S, Tallapragada RM (2013) Effect of bio field treatment on the physical and thermal characteristics of silicon, tin and lead powders. J Material Sci Eng 2: 125.
[28] Smith BC (1998) Infrared spectral interpretation: A Systematic Approach. CRC Press.

[29] Stuart BH (2004) Infrared spectroscopy: Fundamentals and applications (analytical techniques in the sciences (AnTs). John Wiley \& Sons Ltd., Chichester, UK. 